\title{
Nest Survival of Understory Birds in Longleaf Pine Forests Exposed to Fire and Fire-Surrogate Treatments
}

\author{
W. Douglas Robinson ${ }^{*}, 1$ and Ghislain Rompré ${ }^{2}$ \\ ${ }^{I}$ Oak Creek Lab of Biology, Department of Fisheries and Wildlife, Oregon State University, Corvallis, Oregon 97331, \\ USA \\ ${ }^{2}$ Department of Biology and Health Sciences, 84 West South Street, Wilkes University, PA 18766, USA
}

\begin{abstract}
Longleaf pine (Pinus palustris) forest ecosystems evolved with short-interval, low intensity fires. Fire suppression has reduced or eliminated fire and has caused extensive changes in plant community composition and structure. The National Fire and Fire-Surrogate study was implemented to evaluate effects of alternative habitat treatments, such as herbicide application and mechanical thinning, and to compare them with effects of prescribed fire. We evaluated how treatments influenced the nesting success of birds breeding in 10-ha plots of longleaf pine at Solon Dixon Experimental Forest, Alabama. We measured daily rates of nest mortality for 432 nests of 33 species in unmanipulated (controls), burned, herbicide-treated and burned, thinned, and thinned and burned plots during the three years of our study. Although we accumulated observations of 6,624 days that nests were exposed to possible predation, sample sizes were still too small to permit robust statistical analyses of treatment effects. Data from one (Eastern Towhee, Pipilo erythrophthalmus) of two species with the largest sample sizes suggested that nests in treatment plots experienced higher rates of mortality than did nests in control plots, but sample sizes were still small enough that high estimates of variance prevented strong statistical evaluation. Nest survival for the other common species, Northern Cardinal (Cardinalis cardinalis), showed no such suggestive differences. We present results from all nests of all species for which we found three or more nests so that future researchers can use the data during meta-analyses. We also encourage those designing future similar studies to consider expanding the size of study plots so that at least the most numerous open-cup nesting birds can be found in sufficient numbers for strong statistical analyses. In longleaf pine forests of southern Alabama, we estimate that minimum plot sizes would need to be 50 ha for the two most common species, Eastern Towhee and Northern Cardinal.
\end{abstract}

Keywords: Alabama, longleaf pine, fire-surrogates, herbicide, nest survival, prescribed fire, thinning.

\section{INTRODUCTION}

Longleaf pine forests now occur in less than $5 \%$ of their former range across the southeastern United States [1]. In large part, losses were caused by timber harvest, clearing for agriculture, and conversion to woodland dominated by other tree species. Some of this conversion has resulted from suppression of historical fire cycles. Natural low intensity ground fires, typically ignited by lightning or set by Native Americans every two to 8 years [2-4], controlled the community structure of longleaf pine forests and maintained a park-like appearance with low cover of understory shrubs, widely spaced large trees, and a rich forb and grass community. In the absence of fire, vegetation density increased dramatically over time, leading to continuous ground cover, thickets of shrubs and an understory of deciduous tree species, which elevated connectivity of fuels and increased risk of catastrophic fires [5]. Because of this greater fire risk and the desire to preserve the rich vascular plant community and other species characteristic of longleaf pine forests, managers have sought methods to manipulate

*Address correspondence to this author at the Oak Creek Lab of Biology, Department of Fisheries and Wildlife, Oregon State University, Corvallis, Oregon 97331 USA; Tel: 001-541-737-9501; Fax: 001-541-737-3590;

E-mail: douglas.robinson@oregonstate.edu vegetation structure and composition while minimizing risks associated with burning [6]. Two major alternatives, mechanical thinning of understory vegetation and application of herbicides, have been considered. Neither, however, mimics the primary natural disturbance agent, fire. Thus, managers have worried that thinning and herbicides might reduce particular components of longleaf pine forests but fail to create conditions suitable for restoring populations of desired species.

The national Fire and Fire Surrogate Study was designed to evaluate ecological effects of habitat treatments such as mechanical thinning, prescribed burning and combinations of those treatments [7,8]. Ecological effects include responses of wildlife to habitat alteration caused by treatments. Although we know birds respond numerically to changes in habitat characteristics, we know less about effects of such changes on demographic rates. The rate at which birds successfully fledge young from their nests is positively correlated with reproductive success, a primary demographic parameter, and can be estimated by monitoring nests. We sought to quantify nesting success of songbirds in longleaf pine forests exposed to fire and fire surrogate treatments. To do so, we compared nest survival among treatments and unmanipulated controls. 


\section{MATERIALS AND METHODOLOGY}

Study area. Our study was at the 2100-ha Solon Dixon Experimental Forest, near Rome, Alabama (N 31 9' 05" and W $86^{\circ} 41^{\prime}$ ' 9 "). The forest is dominated by longleaf pine. The primary woody understory species is yaupon holly (Ilex vomitoria), but gallberry (Ilex glabra) and huckleberry (Vaccinium spp.) are also common. The site receives approximately $150 \mathrm{~cm}$ of rain per year.

Experimental treatments were applied in a complete randomized block design with three blocks of 5 treatments each. The 15 plots were each approximately 10 ha and gridded with metal posts every $50 \mathrm{~m}$. Treatments included: 1) Prescribed burn during growing season; 2) Thin; 3) Thin plus growing season burn; 4) Herbicide application plus growing season burn; and 5) Untreated control. We had no true pre-treatment data on nest predation rates because the first treatments were applied in early spring of 2002. However, untreated control plots were included. In the strictest sense, the control plots did not have constant conditions because vegetation structure does change over time because of growth or other responses to climatic variation during the study, but compared with treatment plots, conditions in the unmanipulated plots varied relatively little. The control plots had not experienced fire or other treatments for at least 10 years prior to the study. Dates of treatments varied depending on weather and other factors (Table 1). Burned and thinned and burned treatments were burned twice, once in 2002 and once in 2004, to maintain influence of recent fire throughout the study. Herbicide and burned plots were exposed to fire only once.

Table 1. Dates of Treatments in the 12 Longleaf Pine Study Plots at Solon Dixon Experimental Forest, Alabama. Three Plots were Untreated

\begin{tabular}{|c|c|c|c|}
\hline Treatment & Fire & Thinning & Herbicide \\
\hline \hline Burn only & $\begin{array}{c}\text { 23 Apr 2002 and } \\
\text { 6 May 2004 }\end{array}$ & & \\
\hline Burn only & $\begin{array}{c}\text { 15 May 2002 and } \\
\text { 15 Apr 2004 }\end{array}$ & & \\
\hline Burn only & $\begin{array}{c}\text { 21 May 2002 and } \\
\text { 6 Jul 2004 }\end{array}$ & & \\
\hline Thin only & Feb 2002 & \\
\hline Thin only & Mar 2002 & \\
\hline Thin only & Apr 2002 & \\
\hline Thin and Burn & $\begin{array}{c}\text { 29 Apr 2004 } \\
\text { 2902 and }\end{array}$ & Apr 2002 & \\
\hline Thin and Burn & $\begin{array}{c}\text { 22 May 2002 and } \\
\text { Mar 2004 }\end{array}$ & Mar & \\
\hline Thin and Burn & $\begin{array}{c}\text { 5 Apr 2002 and } \\
\text { 28 Apr 2004 }\end{array}$ & Feb 2002 & \\
\hline Herbicide and Burn & 15 Apr 2003 & & 23-28 Sep 2002 \\
\hline Herbicide and Burn & 13 May 2003 & & 28-30 Sep 2002 \\
\hline Herbicide and Burn & 16 Apr 2003 & & $1-2$ Oct 2002 \\
\hline
\end{tabular}

Treatments. Growing season prescribed fires were low intensity and low severity. They were applied with several techniques, including spot fire, back fire, and flanking $[9,10]$, to burned, thinned and burned, and herbicided and burned plots. Thinning aimed to reduce basal area of trees in thinned and thinned and burned plots to $11.5-13.8 \mathrm{~m}^{2} / \mathrm{ha}$. Hardwoods, loblolly pine ( $P$. taedus), spruce pine $(P$. glabra), and slash pine ( $P$. elliottii) were targeted for removal. Plots receiving herbicide application were sprayed with backpack sprayers so that understory (up to $2 \mathrm{~m}$ tall) woody vegetation except longleaf pine could be targeted. An herbicide with $4.5 \%$ Garlon $4^{\mathrm{TM}}$ (triclopyr; Dow AgroSciences, Calgary, Alberta) and Timberline $90^{\mathrm{TM}}$ (UAP Timberland, Monticello, AR) was applied during the fall. Each plot treated with herbicide was then burned the following spring. Additional details are in [5].

To our knowledge, quantification of the vegetation characteristics in the control and treated plots has not been published yet. We summarize here the qualitative changes we observed in the plots. Density of canopy trees was relatively equal across all plots and was largely unaffected by the treatments, although there may have been some delayed mortality after treatments were burned. However, few of our nests were cavity nests, so effects of delayed tree mortality are relatively unimportant here. The strongest effect on vegetation was on the understory. All treated plots had $95 \%$ or more of the understory shrubs removed. The shrub layer was nearly completely removed in all burned plots, leaving only skeletons of some shrubs. Thinning reduced the density of trees less than $10-\mathrm{cm} \mathrm{dbh}$ and the shrub layer, leaving piles of coarse woody debris scattered throughout thinned plots. These piles were burned in the thinned and burned plots. Overall, treatments had a strong effect by reducing understory vegetation density, but a small effect on canopy trees.

Finding and monitoring nests. We found bird nests, primarily in the understory, in each plot from late March through July, 2002-2004. Each plot was searched intensively at least 8 times per season and effort was allocated so that all plots received approximately equal search time. In addition, all plots were visited at least every 4 days to monitor active nests, during which time additional nests were often discovered. When we discovered nests, we marked their locations with flagging tape 5 to $20 \mathrm{~m}$ from the nest sites to facilitate monitoring. We visited nests every 3 to 4 days, depending on the stage of the nesting cycle. Visits were sometimes more frequent near stage changes, such as expected dates of hatch. When monitoring nests, we regularly approached from different directions to reduce chances of creating trails predators might follow to nests. All plots were thoroughly searched, which also reduced the chances of any reward to predators by following human scent trails. We noted clutch size, number of cowbird eggs, and number and identity of young at each visit. Nests above $2 \mathrm{~m}$ were checked with the aid of mirror attached to a pole.

Data analyses. Not all species occurred in all plots, especially after treatments were applied. Treatments affected abundances of birds (Robinson and Rompré, unpubl. data), so sample sizes of nests were uneven across plots.

Methods of statistically comparing nest predation rates across treatments require sample sizes larger than we found in our study plots. For robust analyses, sample sizes per species need to be approximately 40 or more. Population 
densities in longleaf pine forests are simply too low and the plots too small (10 ha) in this study to allow discovery of 40 nests for any bird species. Despite these challenges, information on the nest predation rates of birds is valuable to managers as they weigh strategies for habitat management. Therefore, we present summaries of data for the two most abundant species nesting in the Dixon study plots, but do not present statistical comparisons of nest predation rates. We also present summaries of the raw data for all the other species for which we found at least 3 nests during the study. By presenting data in this manner, we provide the opportunity for others to extract information necessary for future meta-analyses of treatment effects on bird reproductive success in longleaf pine forests.

\section{RESULTS}

We found and monitored 482 nests of 33 species during the three years (Table 2, Appendix 1). Of these, we found 135, 211, and 136 nests in 2002, 2003, and 2004, respectively. The number of exposure days of nests was $1,729,3,102$, and 1,793. As a function of treatment, we found nests in the following numbers (numbers of nests reported as 2002, 2003, 2004): control $(40,50,34)$, burn $(28$, $51,24)$, herbicide (33; no 2003 or 2004 plots were herbicide only), herbicide and burn (no 2002 plots were treated with herbicide and burn; 23, 14), thin $(21,40,18)$, and thin and burn $(13,47,46)$.

The two species for which we found the largest numbers of nests were Eastern Towhee and Northern Cardinal (Table 2). Both species built cup nests in shrubs, although some Eastern Towhees also nested on the ground. Sample sizes ranged from 1 to 18 per plot per year for Eastern Towhees and from two to 14 for Northern Cardinals. Daily mortality rates were highly variable even across years. The patterns of annual variation appeared to share the same general trend in the two species except in control plots. However, because sample sizes of nests were low, variance of estimates were high, so evidence of annual variation is statistically weak. Likewise, evidence of treatment effects was weak. With the exception of the thinned plots, where all Eastern Towhee nests survived to fledge in two of the three years, data suggest that daily mortality rates in the treated plots were higher than those in the untreated controls, but these are only apparent trends, not statistically robust differences. Northern Cardinal nests showed no such trends.

\section{DISCUSSION AND CONCLUSIONS}

Small sample sizes of nests prohibited robust statistical comparisons of treatment effects on avian nesting success. Although data suggested that towhee nests in treated plots experienced higher daily mortality rates than nests in control plots, the effect was probably minor and was too small to be evaluated effectively with statistical approaches commonly employed in these types of studies. If predation rates are related to degree of nest concealment in our study landscape, then it is possible that nests in control plots do experience lower rates of predation. Understory vegetation in control plots was dense, providing abundant cover in which to hide nests of understory birds such as towhees and cardinals. In contrast, understory vegetation in treated plots was sparser but towhees and cardinals continued to nest in those plots, even placing their nests in leafless yaupon hollies that had burned during treatments.

Predation rates, if driven in part by visibility of nests, ought to be greater in situations where burns have exposed nest sites, even if small sample sizes did not provide enough power to detect statistically significant patterns across treatments. However, such risk depends on the responses of predators to the habitat changes. Jones et al. [11] found lower use of burned longleaf pine forests by raccoons (Procyon lotor), a common predator of songbird nests in the southeastern United States. Raccoons used unmanipulated plots more often, suggesting that nests in those plots might be at greater risk to predation even if nests there are better concealed by vegetation. In a comparison of predation rates and predator identity in unmanipulated plots and plots where middle-sized mammalian predators were removed from longleaf pine forests in Georgia, Conner et al. [12] found no treatment effect and discovered that snakes, corvids, and fire ants were the most important predators instead of raccoons. We did not know identity of nest predators at Solon Dixon, but we saw evidence of predation by fire ants only a few times. Snakes were regularly encountered, as were Blue Jays (Cyanocitta cristata). Currently, the effect of the habitat treatments on predator abundance at Solon Dixon is unknown.

Recommendations for minimum sample sizes of nests per treatment and per year have started at twenty [13], but more recent work argues that a minimum of forty nests provides better estimates of variability among plots [14]. Rates of predation on nests of open-cup nesting songbirds are typically variable enough even within habitats and within a breeding season that sample sizes need to be large to capture the variation.

To meet such sample size requirements depends on effectiveness at discovering nests, on population density of each species, on re-nesting rates, and on plot size. The two species providing the largest sample sizes in our study, Eastern Towhee and Northern Cardinal, both occurred commonly in all plots and their open-cup nests were easy to find. We did not have individually marked birds in our plots so we could not ascertain what fraction of nests were re-nests following a loss to predators. However, based on the numbers of nests we discovered in the 10-ha plots, we can estimate that, if we were to use traditional methods for analyzing treatment effects on nest predation rate, we would need to increase the number of nests by four to five times to reach 40 nests per plot in controls and by ten times in the treatment with the smallest sample sizes, plots that experienced herbicide and fire. This would mean, all else being equal, that study plots would need to be a minimum of 100 ha for effective analyses of just the two most common species.

Researchers are often more interested in species of special concern and will use information from common species as surrogates only if data on the species of special interest are unavailable. In longleaf pine forests, the primary species of special concern whose nesting success might be affected by fire and fire surrogate treatments are Redcockaded Woodpecker (Picoides borealis) and Bachman's Sparrow (Aimophila aestivalis). Red-cockaded Woodpeckers 
Table 2. Sample Sizes of Nests (n), Total Exposure Days of Active Nests, and Daily Mortality Rates (DMR; \pm SE) in the Control and Treatment Plots at Solon Dixon Experimental Forest, Alabama, 2002-2004. Data for the Two Species with the Largest Sample Sizes are Included Here

\begin{tabular}{|c|c|c|c|c|c|c|}
\hline Species & Year & Treatment & $\mathbf{n}$ & Exposure (d) & DMR & SE \\
\hline \multirow{10}{*}{ Eastern Towhee } & 2002 & Control & 12 & 180 & 0.0333 & 0.0039 \\
\hline & 2004 & Control & 12 & 121 & 0.0248 & 0.0041 \\
\hline & 2002 & Burn & 9 & 93 & 0.0645 & 0.0085 \\
\hline & 2004 & Burn & 7 & 87 & 0.0456 & 0.0085 \\
\hline & 2002 & Herb & 16 & 244 & 0.0164 & 0.0020 \\
\hline & 2003 & Herb \& burn & 5 & 47 & 0.1063 & 0.0201 \\
\hline & 2004 & Herb \& burn & 1 & 12 & 0.0833 & 0.0798 \\
\hline & 2002 & Thin \& Burn & 4 & 33 & 0.0909 & 0.0909 \\
\hline & 2003 & Thin \& Burn & 9 & 146 & 0.0342 & 0.0050 \\
\hline & 2004 & Thin \& Burn & 18 & 138 & 0.1014 & 0.0060 \\
\hline \multirow{10}{*}{ Northern Cardinal } & 2002 & Control & 5 & 77 & 0 & 0 \\
\hline & 2003 & Control & 14 & 133 & 0.0751 & 0.0061 \\
\hline & 2004 & Control & 8 & 116 & 0.0345 & 0.0060 \\
\hline & 2002 & Burn & 11 & 112 & 0.0625 & 0.0069 \\
\hline & 2003 & Burn & 14 & 190 & 0.0368 & 0.0036 \\
\hline & 2003 & Thin & 11 & 130 & 0.0538 & 0.0060 \\
\hline & 2004 & Thin & 4 & 70 & 0.0286 & 0.0099 \\
\hline & 2002 & Thin \& Burn & 2 & 27 & 0.0741 & 0.0356 \\
\hline & 2003 & Thin \& Burn & 7 & 109 & 0.0367 & 0.0068 \\
\hline & 2004 & Thin \& Burn & 5 & 54 & 0.0556 & 0.0139 \\
\hline
\end{tabular}

were not found in any of our study plots. Bachman's Sparrows were not found in any plot prior to treatments, but colonized two plots after prescribed fire and produced young in at least one of the plots. We did not find nests of Bachman's Sparrows in the burned plots, but data from nearby Conecuh National Forest indicate that sites burned during the growing season had the highest sparrow population densities and that, if all nests were found in an area with the highest densities of breeding pairs, plots would need to be a minimum of 80 ha to produce 40 nests [15]. Yet, Bachman's Sparrows nearly disappear completely from sites that remain unburned for 6 or more years, so comparisons of treatment effects could be even more challenging. In summary, longleaf pine ecosystems do not support great densities of songbirds [16], so use of traditional methods to compare nesting success across treatments will always be challenging unless treated areas can be very large, on the order of 100 ha or more.

Besides designing studies that use larger plots, if managers wish to understand effects of treatments on avian nesting success, the best way forward is likely to be through meta-analyses that utilize data gathered at multiple sites. Such meta-analyses can only be accomplished if data are published and presented in ways that allow effective harvesting of the information for further analyses. We encourage researchers to publish their results when possible 
so that data can be discovered and analyzed by interested researchers. That desire was the motivation behind this special issue and publication of other nesting success data from the fire-fire surrogate study $[17,18]$. Alternatively, data can be archived in repositories such as the Avian Knowledge Network. However, extensive meta-data and associated materials, akin to what would be included in a peer-reviewed publication, should be provided so that those conducting meta-analyses may have enough information to interpret the archived data accurately.

\section{ACKNOWLEDGEMENTS}

This is Contribution Number 214 of the National Fire and Fire Surrogate (FFS) Research Project, which was funded by the U.S. Joint Fire Science Program. We are grateful to our many field assistants who helped find and monitor nests: J. Lowe, B. Palser, C. Riemer, G. Gareau, J. Diener, and C. Enloe. We also thank R. Johnson, D. Pancake, M. Hainds, and K. Outcalt for facilitating our work at the Solon Dixon Experimental Forest. We thank two reviewers for their insightful comments.

\section{APPENDIX 1}

Sample sizes of nests of most species were too small to allow statistical evaluations of treatment effects. To facilitate future meta-analyses, we report sample sizes of nests (n), number of nests failing to fledge young, and total exposure days of nests in the plots at Solon Dixon Experimental Forest, Alabama, 2002-2004, for species with more than 3 nests during found during our study. Species are listed in alphabetical order by common name. Abbreviations for treatments are Control $(\mathrm{C})$, Herbicide $(\mathrm{H})$, Herbicide and burn (HB), Thin (T), and Thin and burn (TB). Bird species are listed in alphabetical order by common name.

\begin{tabular}{|c|c|c|c|c|c|}
\hline Species & Year & Treatment & $\mathbf{N}$ & Failures & Exposure (d) \\
\hline \multirow{12}{*}{$\begin{array}{l}\text { Blue-gray } \\
\text { Gnatcatcher }\end{array}$} & \multirow{3}{*}{2002} & $\mathrm{C}$ & 3 & 1 & 46 \\
\hline & & $\mathrm{H}$ & 1 & 1 & 14 \\
\hline & & TB & 1 & 0 & 10 \\
\hline & \multirow{5}{*}{2003} & $\mathrm{C}$ & 4 & 0 & 58 \\
\hline & & B & 3 & 0 & 58 \\
\hline & & HB & 1 & 0 & 26 \\
\hline & & $\mathrm{T}$ & 1 & 0 & 29 \\
\hline & & TB & 2 & 2 & 25 \\
\hline & \multirow{4}{*}{2004} & $\mathrm{C}$ & 1 & 0 & 31 \\
\hline & & B & 1 & 0 & 28 \\
\hline & & HB & 2 & 1 & 44 \\
\hline & & TB & 1 & 0 & 3 \\
\hline \multirow{4}{*}{ Blue Grosbeak } & 2002 & B & 1 & 1 & 2 \\
\hline & \multirow{2}{*}{2003} & B & 1 & 0 & 26 \\
\hline & & TB & 1 & 0 & 24 \\
\hline & 2004 & B & 3 & 2 & 17 \\
\hline
\end{tabular}

\begin{tabular}{|c|c|c|c|c|c|}
\hline Species & Year & Treatment & $\mathbf{N}$ & Failures & Exposure (d) \\
\hline \multirow{7}{*}{ Blue Jay } & \multirow{2}{*}{2002} & $\mathrm{C}$ & 2 & 2 & 51 \\
\hline & & $\mathrm{H}$ & 1 & 1 & 12 \\
\hline & \multirow{5}{*}{2003} & $\mathrm{C}$ & 2 & 0 & 38 \\
\hline & & B & 3 & 0 & 56 \\
\hline & & HB & 1 & 0 & 33 \\
\hline & & $\mathrm{T}$ & 1 & 0 & 27 \\
\hline & & $\mathrm{TB}$ & 2 & 1 & 29 \\
\hline \multirow{8}{*}{$\begin{array}{l}\text { Brown } \\
\text { Thrasher }\end{array}$} & \multirow{3}{*}{2002} & B & 1 & 0 & 9 \\
\hline & & $\mathrm{T}$ & 1 & 1 & 3 \\
\hline & & TB & 2 & 2 & 5 \\
\hline & \multirow{2}{*}{2003} & B & 1 & 1 & 17 \\
\hline & & TB & 3 & 2 & 35 \\
\hline & \multirow{3}{*}{2004} & HB & 1 & 1 & 7 \\
\hline & & $\mathrm{T}$ & 2 & 0 & 41 \\
\hline & & $\mathrm{TB}$ & 10 & 4 & 155 \\
\hline \multirow{5}{*}{$\begin{array}{c}\text { Carolina } \\
\text { Chickadee }\end{array}$} & 2002 & $\mathrm{C}$ & 1 & 0 & 20 \\
\hline & \multirow{4}{*}{2003} & B & 1 & 0 & 20 \\
\hline & & HB & 3 & 1 & 74 \\
\hline & & $\mathrm{T}$ & 1 & 1 & 13 \\
\hline & & $\mathrm{TB}$ & 1 & 1 & 7 \\
\hline \multirow{8}{*}{$\begin{array}{c}\text { Carolina } \\
\text { Wren }\end{array}$} & 2002 & $\mathrm{C}$ & 2 & 1 & 28 \\
\hline & \multirow{2}{*}{2003} & $\mathrm{HB}$ & 2 & 2 & 29 \\
\hline & & $\mathrm{T}$ & 1 & 1 & 19 \\
\hline & \multirow{5}{*}{2004} & $\mathrm{C}$ & 2 & 1 & 35 \\
\hline & & B & 1 & 1 & 20 \\
\hline & & HB & 1 & 1 & 1 \\
\hline & & $\mathrm{T}$ & 2 & 2 & 32 \\
\hline & & $\mathrm{TB}$ & 2 & 1 & 37 \\
\hline \multirow{6}{*}{$\begin{array}{l}\text { Chuck-will's- } \\
\text { widow }\end{array}$} & \multirow{2}{*}{2002} & $\mathrm{C}$ & 1 & 1 & 27 \\
\hline & & B & 1 & 0 & 1 \\
\hline & \multirow{2}{*}{2003} & $\mathrm{C}$ & 1 & 1 & 6 \\
\hline & & HB & 1 & 1 & 1 \\
\hline & \multirow{2}{*}{2004} & $\mathrm{C}$ & 1 & 1 & 10 \\
\hline & & $\mathrm{HB}$ & 1 & 1 & 3 \\
\hline \multirow{3}{*}{$\begin{array}{c}\text { Downy } \\
\text { Woodpecker }\end{array}$} & 2002 & $\mathrm{~T}$ & 1 & 0 & 2 \\
\hline & \multirow{2}{*}{2003} & B & 1 & 0 & 17 \\
\hline & & $\mathrm{T}$ & 1 & 0 & 18 \\
\hline \multirow{3}{*}{$\begin{array}{c}\text { Eastern } \\
\text { Wood-Pewee }\end{array}$} & \multirow{3}{*}{2002} & C & 2 & 0 & 8 \\
\hline & & B & 1 & 1 & 12 \\
\hline & & TB & 1 & 0 & 10 \\
\hline
\end{tabular}




\begin{tabular}{|c|c|c|c|c|c|}
\hline Species & Year & Treatment & $\mathbf{N}$ & Failures & Exposure (d) \\
\hline \multirow{8}{*}{$\begin{array}{c}\text { Eastern } \\
\text { Wood-Pewee }\end{array}$} & \multirow{3}{*}{2003} & $\mathrm{C}$ & 1 & 0 & 4 \\
\hline & & $\mathrm{T}$ & 3 & 0 & 62 \\
\hline & & TB & 2 & 1 & 29 \\
\hline & \multirow{5}{*}{2004} & $\mathrm{C}$ & 1 & 0 & 14 \\
\hline & & B & 1 & 1 & 10 \\
\hline & & HB & 1 & 0 & 33 \\
\hline & & $\mathrm{T}$ & 1 & 1 & 3 \\
\hline & & TB & 1 & 1 & 18 \\
\hline \multirow{6}{*}{$\begin{array}{l}\text { Great Crested } \\
\text { Flycatcher }\end{array}$} & 2002 & TB & 2 & 1 & 23 \\
\hline & \multirow{4}{*}{2003} & $\mathrm{C}$ & 3 & 1 & 44 \\
\hline & & HB & 1 & 0 & 19 \\
\hline & & $\mathrm{T}$ & 2 & 1 & 51 \\
\hline & & TB & 4 & 0 & 88 \\
\hline & 2004 & TB & 3 & 2 & 55 \\
\hline \multirow{4}{*}{$\begin{array}{l}\text { Indigo } \\
\text { Bunting }\end{array}$} & \multirow{2}{*}{2002} & $\mathrm{C}$ & 2 & 0 & 49 \\
\hline & & $\mathrm{T}$ & 1 & 1 & 19 \\
\hline & 2003 & B & 5 & 4 & 59 \\
\hline & 2004 & $\mathrm{C}$ & 1 & 1 & 21 \\
\hline \multirow{10}{*}{$\begin{array}{l}\text { Mourning } \\
\text { Dove }\end{array}$} & \multirow{3}{*}{2002} & $\mathrm{C}$ & 3 & 2 & 30 \\
\hline & & $\mathrm{H}$ & 3 & 3 & 28 \\
\hline & & $\mathrm{T}$ & 1 & 0 & 23 \\
\hline & \multirow{4}{*}{2003} & $\mathrm{C}$ & 1 & 1 & 3 \\
\hline & & B & 2 & 1 & 13 \\
\hline & & $\mathrm{T}$ & 4 & 4 & 50 \\
\hline & & TB & 2 & 1 & 12 \\
\hline & \multirow{3}{*}{2004} & $\mathrm{C}$ & 1 & 1 & 15 \\
\hline & & B & 1 & 1 & 18 \\
\hline & & TB & 1 & 1 & 21 \\
\hline \multirow{3}{*}{$\begin{array}{c}\text { Northern } \\
\text { Mockingbird }\end{array}$} & \multirow{2}{*}{2003} & $\mathrm{HB}$ & 1 & 1 & 3 \\
\hline & & $\mathrm{TB}$ & 2 & 2 & 27 \\
\hline & 2004 & TB & 1 & 1 & 15 \\
\hline \multirow{6}{*}{$\begin{array}{l}\text { Pine } \\
\text { Warbler }\end{array}$} & \multirow{2}{*}{2002} & $\mathrm{C}$ & 2 & 0 & 23 \\
\hline & & $\mathrm{T}$ & 1 & 0 & 3 \\
\hline & \multirow{4}{*}{2003} & $\mathrm{C}$ & 3 & 0 & 13 \\
\hline & & B & 1 & 0 & 4 \\
\hline & & $\mathrm{T}$ & 2 & 0 & 30 \\
\hline & & TB & 3 & 0 & 10 \\
\hline \multirow{4}{*}{$\begin{array}{l}\text { Prairie } \\
\text { Warbler }\end{array}$} & \multirow{2}{*}{2002} & $\mathrm{C}$ & 1 & 0 & 19 \\
\hline & & $\mathrm{H}$ & 2 & 0 & 12 \\
\hline & \multirow{2}{*}{2003} & $\mathrm{C}$ & 1 & 0 & 25 \\
\hline & & B & 4 & 3 & 61 \\
\hline
\end{tabular}

\begin{tabular}{|c|c|c|c|c|c|}
\hline Species & Year & Treatment & $\mathbf{N}$ & Failures & Exposure (d) \\
\hline \multirow{9}{*}{$\begin{array}{l}\text { Red-bellied } \\
\text { Woodpecker }\end{array}$} & \multirow{3}{*}{2002} & $\mathrm{C}$ & 1 & 0 & 4 \\
\hline & & B & 1 & 1 & 3 \\
\hline & & $\mathrm{T}$ & 1 & 0 & 28 \\
\hline & \multirow{4}{*}{2003} & $\mathrm{C}$ & 3 & 0 & 95 \\
\hline & & B & 1 & 0 & 27 \\
\hline & & HB & 2 & 1 & 41 \\
\hline & & $\mathrm{T}$ & 2 & 0 & 88 \\
\hline & \multirow{2}{*}{2004} & $\mathrm{C}$ & 3 & 0 & 66 \\
\hline & & $\mathrm{T}$ & 1 & 0 & 12 \\
\hline \multirow{11}{*}{$\begin{array}{l}\text { Summer } \\
\text { Tanager }\end{array}$} & \multirow{3}{*}{2002} & $\mathrm{C}$ & 2 & 1 & 41 \\
\hline & & $\mathrm{H}$ & 1 & 0 & 27 \\
\hline & & $\mathrm{T}$ & 1 & 1 & 15 \\
\hline & \multirow{4}{*}{2003} & $\mathrm{C}$ & 2 & 0 & 53 \\
\hline & & B & 1 & 1 & 7 \\
\hline & & $\mathrm{T}$ & 2 & 1 & 24 \\
\hline & & $\mathrm{TB}$ & 2 & 1 & 29 \\
\hline & \multirow{4}{*}{2004} & $\mathrm{C}$ & 1 & 0 & 25 \\
\hline & & B & 1 & 1 & 13 \\
\hline & & HB & 2 & 1 & 41 \\
\hline & & TB & 2 & 0 & 24 \\
\hline \multirow{5}{*}{$\begin{array}{l}\text { White-eyed } \\
\text { Vireo }\end{array}$} & \multirow{2}{*}{2002} & B & 1 & 0 & 26 \\
\hline & & $\mathrm{T}$ & 1 & 0 & 13 \\
\hline & \multirow{2}{*}{2003} & $\mathrm{C}$ & 1 & 0 & 3 \\
\hline & & HB & 1 & 0 & 16 \\
\hline & 2004 & $\mathrm{C}$ & 1 & 1 & 21 \\
\hline \multirow{6}{*}{$\begin{array}{l}\text { Wild } \\
\text { Turkey }\end{array}$} & \multirow{3}{*}{2002} & $\mathrm{C}$ & 1 & 1 & 3 \\
\hline & & $\mathrm{H}$ & 2 & 2 & 26 \\
\hline & & $\mathrm{T}$ & 1 & 1 & 1 \\
\hline & \multirow{2}{*}{2003} & $\mathrm{C}$ & 1 & 1 & 1 \\
\hline & & $\mathrm{T}$ & 2 & 2 & 23 \\
\hline & 2004 & $\mathrm{C}$ & 2 & 2 & 9 \\
\hline \multirow{3}{*}{$\begin{array}{l}\text { Yellow-billed } \\
\text { Cuckoo }\end{array}$} & 2003 & TB & 2 & 0 & 30 \\
\hline & \multirow{2}{*}{2004} & $\mathrm{~T}$ & 1 & 1 & 1 \\
\hline & & TB & 1 & 0 & 6 \\
\hline
\end{tabular}

\section{REFERENCES}

[1] Outcalt KW, Sheffield RM. The longleaf pine forests: trends and current conditions. Resource Bulletin SRS-9. U.S. Asheville, NC: Department of Agriculture, Forest Service, Southern Research Station 1996.

[2] Christensen NL. Fire regimes in southeastern ecosystems. In: Mooney HA, Bonnicksen TM, Christensen NL, Lotan JE, Reiners WA, Tech Coords Eds. Proceedings, Conference Fire Regimes and Ecosystem Properties. Gen. Tech. Rep. WO-26. Washington, DC: USDA Forest Service 1981; pp112-36. 
[3] Abrahamson WG, Hartnett DC. Pine flatwoods and dry prairies. In: Myers RL, Ewel JJ, Eds. Ecosystems of Florida. Orlando, FL: University of Central Florida Press 1990; pp 103-49.

[4] Ware S, Frost C, Doerr PD. Southern mixed hardwood forest: the former longleaf pine forest. In: Martin WH, Boyce SG, Echternacht AC, Eds. Biodiversity of the Southeastern United States: Lowland Terrestrial Communities. New York: John Wiley and Sons 1993; pp 447-93.

[5] Schwilk D, Keeley JE, Knapp EE, et al. The national Fire and Fire Surrogate study: effects of fuel reduction methods on forest vegetation structure and fuels. Ecol Appl 2009; 19: 285-304.

[6] Agee JK, Skinner CN. Basic principles of forest fuel reduction treatments. For Ecol Manage 2005; 211: 83-96.

[7] Weatherspoon CP. A proposed long-term national study of the consequences of fire and fire-surrogate treatments. In: Neuenschwander LF, Ryan KC, Goldberg GE, Eds. Proceedings of the Joint Fire Science Conference and Workshop: Crossing the millennium: Integrating spatial technologies and ecological principles for a new age in fire management. Moscow, Idaho: University of Idaho Press 2000; pp 117-26.

[8] Boerner REJ, Hart SC, McIver JD. The national fire and fire surrogate study: Ecological consequences of alternative fuel reduction methods in seasonally dry forests. For Ecol Manage 2008; 255: 3075-80.

[9] Outcalt KW. Developing management options for longleaf communities of the Gulf Coastal Plain. Proceedings of the Fourth Longleaf Alliance Regional Conference, Longleaf Alliance Report $6 ; 2003 ; 126-9$.
[10] Kennard DK, Outcalt KW, Jones D, O’Brien JJ. Comparing techniques for estimating flame temperature of prescribed fires. Fire Ecol 2005; 1: 75-84.

[11] Jones DD, Conner LM, Storey TH, Warren RJ. Prescribed fire and raccoon use of longleaf pine forests: implications for managing nest predation? Wildl Soc Bull 2004; 32: 1255-9.

[12] Conner LM, Rutledge JC, Smith LL. Effects of mesopredators on nest survival of shrub-nesting songbirds. J Wildl Manage 2010; 74: 73-80.

[13] Hines JE, Sauer JR. Program CONTRAST: A general program for the analysis of several survival or recovery rate estimates. U.S. Fish and Wildlife Service, Fish and Wildlife Technical Report No. 24, 1989; pp1-7.

[14] Rotella J, Taper M, Stephens S, Lindberg M. Extending methods for modeling heterogeneity in nest-survival data using generalized mixed models. Stud Avian Biol 2007; 34: 34-44.

[15] Tucker JW, Robinson WD, Grand JB. Influence of fire on Bachman's Sparrow, an endemic North American songbird. J Wildl Manage 2004; 68: 1114-23.

[16] Engstrom RT, Crawford RL, Baker WW. Breeding bird populations in relation to changing forest structure following fire exclusion: a fifteen-year study. Wilson Bull 1984; 96: 437-50.

[17] Kilpatrick E, Lanham JD, Waldrop TA. Effects of fuel reduction treatment on avian nest density in the Upper Piedmont of South Carolina. Open Environ Sci J 2010; 4: 78-83.

[18] Streby HM, Miles DB. Assessing ecosystem restoration alternatives in eastern deciduous hardwood forests using avian nest survival. Open Environ Sci J 2010; 4: 39-48. 